\title{
Analysis of Socioeconomic Factors that Dampen the Flow of Foreign Direct Investment
}

\author{
Khawaja Asif Mehmood \\ School of Economics Finance and Banking, College of Business, Universiti Utara Malaysia \\ Email: khawjaasif@bzu.edu.pk \\ Sallahuddin Hassan \\ School of Economics, Finance and Banking, Universiti Utara Malaysia \\ Corresponding Author email: din636@uum.edu.my
}

Doi:10.5901/mjss.2015.v6n4s3p578

\begin{abstract}
It is difficult to neglect the prominence of socio-economic factors that dampen the flow of Foreign Direct Investment (FDI) to a country, inspite of either being developed or developing. This study, however, looked into such factors that affect FDI inflows towards Pakistan. This study gains appreciable position due to an attempt of looking into the theoretical perception, some of whom are tested while others are not, that explain such determinants of FDI. Exercising Auto Regressive Distributed Lag (ARDL) technique of investigation on data ranging from 1974 to 2014 along with Error Correction Model (ECM) and bound test, some interesting facts, apart from conventional, though not in Pakistan or either quite rare, are found on the socioeconomic variables mix chosen in this research. It is suggested that the government is to look for specific policies to cater the problem of corruption that is found as a major hinge in the way of FDI inflows.
\end{abstract}

Keywords: Foreign Direct Investment; Political Stability; Corruption; Auto Regressive Distributed Lag; Bound Test.

\section{Introduction}

\subsection{Background of the study}

An investment is known to be as accumulation of assets in order to get a reward in the shape of profit from it. For achieving economic growth and development, consistency amongst the accumulation of such assets is indeed required. Basically, investment is categorized into FDI and foreign portfolio investment (FPI). Amongst the two, FDI varies from medium to long-term. It is because of executing managerial controls over the country's capital where it flows. Ragazzi (1973) argued that for effective controls, on business and productive activity, FDI is an investment done in foreign enterprises by the residents of a particular country. Bashir, Mansha, Zulfiqar, and Riaz (2014) argued that for the last two centuries, FDI has attained a significant importance after it is realized as important determinant of economic growth and development.

Like several developing countries, Pakistan also faces gaps between domestic saving and investment. Here, FDI play significant role in filling up such gaps. Nevertheless, such inflows help in expanding the process of job creation, diversify the state of new technology, expand national output, and perhaps the growth level (Ataullah, Cockerill, \& Le, 2004). In Pakistan, for the development process of the country and indeed for achieving targeted rate of economic growth, FDI can play a central role. The government of Pakistan is trying the level best to fix up all of the economic, political and social concerns in a country for being considered as a good host for the foreign investors. The motivational factor of the present study rests on the empirical findings on how some of the socioeconomic variables tease up the most integral determinant of economic growth and prosperity of a particular country.

\subsection{Problem Statement}

For countries like Pakistan that tends to be more open and globalized in terms of receiving foreign inflows, FDI is of immense importance. The goals like that of economic growth, eradication of poverty, enhancement in the rate of labor force participation, proliferation in the overall export quality product range, and other macroeconomic objectives cannot be achieved unless there is presence of significant and persistent flow of FDI. However, in this regard the intent of 
economic, political, and social problems that are in association to physical infrastructure must be empirically investigated in terms of confirming that for how much intensity these problems affect the persistent flow of FDI to Pakistan.

FDI being an important factor for addressing the economic issues of its recipient country is affected by the prevailing economic atmosphere in a certain country. Past trends on account of the flow of FDI into Pakistan show that Greenfield investment has been prevailing in the range that exceeds USD1000 million, in the year 2004-05 to 2010-11. It gained highest peak in the year 2010-11, standing at the level of USD1634million. It is alarming to notice that such privatization proceeds came to nil during 2008-09 to 2011-12. Private portfolio investment, since 2001- 02 till 2012-13 has been seen changing dramatically i.e. reaching its highest peak of USD1820 million in the year 2006-07 but turned to negative in couple of years like in 2002, 2004, 2009 and 2012.

However, according to the economic survey of Pakistan 2013-14, foreign private investment witnessed a decline of 15 percent mainly emanating from FDI which reduced by 12.9 percent. Inflows of FDI were USD1604 million during first ten months of financial year 2013-2014. FDI from July to April, 2014 remained depressed at USD750.9 million as compared to USD862.3 million during the same period last fiscal year. As stated in the Economic Survey of Pakistan, issued by the Ministry of Finance (2014); that foreign investment has posted some surge, however, it feels that adverse law and order situation and energy crisis are still major hurdles in bringing up sufficient level of foreign investment. "We are expecting more foreign investment in oil, gas and energy sector as the country is facing energy crisis and uncertain economic situation from last few years", said (Ministry for Finance, Government of Pakistan, 2014).

Today in Pakistan, there are found political conflicts among political parties. They have created a situation of unrest in whole country. Several important visits of foreign delegates are held cancelled just for the sake of life threats and abrupt law and order situation, mainly in the capital city, Islamabad, Pakistan. The trends and patterns of GDP growth rate of Pakistan since for the last one decade are not that appreciable and stable, mainly due to energy crisis severity and political disorders. The government has not yet achieved its targeted growth rate of 3.5 percent. This depressed state of economic growth, supplemented with other macroeconomic problems put serious questions before the foreign investors in their thinking of investing their heavy capital in such regions.

On account of trade, Pakistan suffers from the problems in respect of unachieved targets of exports. It is mainly because of the prevailing high inflationary pressures in a country, insufficient FDI and indeed the energy crises in term of severe shortage of electricity and natural gas. This altogether is resulting in firstly not enabling Pakistan to meet the export order and secondly high cost of production makes the products unattractive in foreign market. All these situations alter the mind of foreign investors who wish to invest in Pakistan. There are problems of volatile foreign exchange market (FOREX). The propensity of variability in FOREX market is very rapid and frequent. This is of a serious concern for the foreign investors who have to bear all the burdens while they ought to import some raw material or intermediate goods from abroad.

From theoretical back ground, it is found that FDI helps in boosting the economic growth rate of the host country more than that of the contribution in the same regard by the local firms. In this case, if economic, political and social disturbance prevail in a country, such dilemma will not only depress the smooth and persistent flow of FDI rather will promote the existing firms to think of investing their capital abroad. Nonetheless, all of these aspects together will not enable the particular state to carry-on with the progress in economic growth. It is because of the fact that all these variables affect level of FDI flows to a particular country (Wheeler \& Mody, 1992; Singh \& Jun, 1995; Mehmood \& Faridi, 2013). Therefore, it really becomes a matter of question that "In the presence of such vulnerable situations on account of some of the socio-economic indicators, would it be sufficiently possible for Pakistan to still be attractive for the foreign investors"?

\subsection{Significance and Scope of Study}

Studies on FDI are significant due the reason that such inflows are the sources of capital accumulation in the host country which is indeed an important determinant of economic growth, enhancing domestic savings, tax revenue, export receipts, and most importantly the employment creation. Therefore, the factors that are the hindrances in the way of FDI flows are un-tolerable. This study attempts to add to the existing literature in the way that is supplemented with the empirical investigation of socioeconomic variables that are the causes for the unclear and inconsistent patterns of FDI flow, especially towards Pakistan.

This buildup of nexus between socioeconomic factors and FDI enchanters the importance of the study, thus makes it meaningful in terms of the interpretation of the causes of such volatile flow of FDI, upon which the economic prosperity of Pakistan rests. By this study, not only do the government of Pakistan rather all the political parties as well as the business class of Pakistan will be helped in knowing about the factors that are positive and or negative in their behavior 
towards FDI. This study is for sure to facilitate the policy makers (bureaucracy and establishment) to look for the possibilities for capturing weighty and persistent flow of FDI to Pakistan, that is not only a need for today rather is a basic ingredient for the future development and healthier standing of the state in the global world.

This study is aimed to utilize time series analysis for capturing the behavior of FDI against various internal factors that prevail in Pakistan. The statistical tools which are worked along in the present research are to help in realizing not only the effects of either of the selected variables on FDI flows to Pakistan, rather also trace for the direction, in terms of short run, and long run effects on FDI. Pakistan being developing country of the world is currently facing volatile trend of FDI flows that is off course a hindrance in the way of achieving the national growth targets and of enhancing the exports base. Thus, this study encompasses with a due weight-age in terms of pointing out some of the internal issues that are the causes of such volatile flow of FDI to Pakistan.

\subsection{Organization of the Study}

This study composes six sections. In prelim state, i.e. Section I after highlighting brief introduction, explains about the back ground of study on the bases of which this research is reliant. Furthermore, state of problem on account of Pakistan in terms of the macroeconomic disturbances are discussed that enabled to frame up the description on the significance and scope of this proposed research. In Section II, there are discussed empirical evidences to justify the relationship between FDI and its determinants opted in this study. Subsequently, in Section III, brief outlook of the relevant theories of FDI is given. In section IV, model specification, sources of the data collection and the methods of analyses are explained that lead to the results and discussion, as are brought out in section V. Lastly, Section VI is dosed to explicate the policy suggestion(s) and the conclusion.

\section{The Review of Literature}

\subsection{Interplay of Economic Growth and Foreign Direct Investment}

In order of discussing about the determinants of FDI in view of the previous researches, firstly there is a need to highlight the reason(s) for the importance of study on FDI. Capturing the significance of FDI, it is viewed as one of the main determinants of economic growth of a particular country. So, as economic growth is a key factor of development then a factor in terms of FDI that effects the economic growth must be viewed for how it is affected by other exogenous factors.

Economic growth is found as determined by FDI (Kindleberger, 1969; Caves, 1974; Zaman, Rasheed, Khan, \& Ahmad, 2011; Yousaf, Hussain, \& Ahmad, 2008). Studies like of Grosse and Trevino (1996), Sarno and Taylor (1999), Kesteloot and Veugelers (1995), and Barrell and Pain (1996) concentrated on the notion that economic growth of a country determines flow of FDI. Nevertheless, FDI is also found possessing positive effects onto the economic growth of the host country, in reciprocation (Borensztein, Gregorio, \& Lee, 1998). However, the effects are found significant when political stability exists on account of the recipient country (Zhang, 2001).

The interplay of FDI and GDP is common in the past literatures. Thus, makes GDP as one of the main determinants of FDI. Based on vector autoregressive model (VAR) that was used for analyzing the data from 1973 to 2008, Safdari and Mehrizi (2011) worked with the multiple regression analysis by using Johansen Juselius (1990) test of cointegration, the study explored that the labor force participation, FDI and internal investment have had positive associations with that of the economic growth of Iran.

\subsection{The Determinants of FDI}

Foreign investors and their decisions to bring up investment into a particular country for instance, depend upon the state of macroeconomic factors of a particular country. Such are the determinants of FDI (Khan \& Khan, 2011; Mehmood \& Faridi, 2013). Looking into the effects of FDI on growth, Chaudhary, Iqbal and Gillani (2009) found that the effects of FDI are always indicating as fostering the growth process of the host country in terms of the involvement of other factors like that of human capital, employed labor force, domestic saving and the balance of payment at appropriate state of position.

In capturing the data from 1975 to 2008 in line with the ARDL, the study conducted by Rehman, llyas, Mobeen and Akram (2011) found that real exchange rate, market size and the local infrastructure (in terms of the importation of machinery) brought positive and significant effect on the flow of FDI to Pakistan. Same results on accord of Johansen Juselius (1990) technique and ECM were depicted by Abbas, Akbar, Nasir, Ullah and Naeem (2011). Nevertheless, adding up into the range of independent variables that act as either incitement or deterrent to FDI, Mahmood, Ehsanullah 
and Ahmed (2011) came up with the introduction of democracy and secondary school enrollment in tracing for the effects of the same on FDI flows to Pakistan. Exercising methodological techniques of ordinary least square (OLS), the study explored the facts that democracy and secondary enrollment brought significant positive effects on FDI, unlike real exchange rate, exports and import duties.

Several econometric techniques and diverse sample size are used in incorporating the contribution in the research field of highlighting for the effects of different macroeconomic variables on FDI inflows to the particular country. For example Tsai (1994) focused on 62 developing countries for the range of data from 1962 to 1984 . The methodology used was of two-stage least square statistical analyzes system. The results showed for GDP and volume of trade as positively effecting FDI inflows. However, country specific effects were investigated by large sample size range of 34 years i.e. from 1974 to 2008 by Mohiudin and Salam (2011). Like study of Shaikh and Ansari (2011), the study based upon technique of OLS multiple regressions. The results of the study found to be the same in terms of effects of GDP on FDI as were previously quoted by Tsai (1994) however, with different analytical technique.

Studies conducted earlier, based upon the technique of Johansen Juselius (1990) model of cointegration were forwarded by Aqeel, Nishat and Bilquees (2005) and Mehmood and Faridi (2013). The study of Aqeel et al. (2005) focused on investigating for the effects of corporate taxes on FDI and Mehmood and Faridi (2013) focused on variables like that of labor force participation, GDP, trade openness, interest rate, political stability, inflation and exchange rate. These studies came up with findings that corporate taxes posted negative effects on FDI flows. However, GDP, trade openness and political stability brought up positive effects on FDI into Pakistan.

\subsection{FDI and Political Stability}

Good governance and political stability are the two important determinants of FDI (Mehmood \& Faridi, 2013). Political instability, however, effects the economic growth process of a country, in negative (Javed, Falak, Awan, \& Ashraf, 2012). Somehow measuring FDI against political instability, mixed results are found, if we compare the trends of results in past studies (Kobrin, 1984; Scheider \& Frey, 1985). However, Knack and Keefer (1995) suggested that political instability adversely affects the issues of growth and investment. Political instability is serious issue in developing countries that impinges smooth flows of foreign capital (Scheider \& Frey, 1985). It is the most powerful factor that depresses the FDI (Fry, Clasessens, \& Burridge, 1995). In case of Asian Economies, political stability stands as vital in its role for economic growth. Its effects are transformed to economic growth of a particular country in response to accumulation of capital, in terms of human capital, and foreign capital inflows, such as FDI (Younis, Lin, \& Sharahili, 2008).

\subsection{FDI and Corruption}

Study of Aburine (2010), on Nigeria, found that massive traces of corruption on account of public sector, mainly, effect in negative, the economic growth as well as flow of FDI. It is one of the major issues towards the development of a country (Shahbaz \& Rahman, 2010). High rate of corruption is negative in association to FDI (Zhou, 2007). Cross sectional study in this regard, conducted by Al-Sadig (2009) on 117 countries found corruption as negative in relation to FDI in all of the selected countries in the study. Habib and Zurawicki (2002), in supporting to Akcay (2001) published their findings that corruption bears negative relationship to the FDI. Nevertheless, in this respect Laran and Tavare (2004) suggested the same findings in terms of examining the causality effects of corruption and FDI. The study found FDI excelled in reference to the lower corruption, at government level.

\section{$2.5 \mathrm{FDI}$ and Interest Rate}

It cannot be kept unobserved that interest rate differential among various countries carry profound effects, either in negative or in positive, on the FDI flow to a particular country. Whenever capital funds are raised from the source country where capital in comparatively cheap, the investors face heavy competition in acquisition of funds. However, FDI being positive in response to high real interest rate in host country turns to behave otherwise if foreign investors are to depend upon the host country for getting capital (Grosse \& Trevino, 1996). Unlike of the study of Akhtar (2000), who found FDI as positive in repel of higher interest rates, the rate of interest that is a cost of borrowing funds if is high, effects the decisions for investments in negative (Zaman, Shah, Khan, \& Ahmad, 2012). 


\subsection{FDI and Inflation}

Higher rate of inflation is the reflection of imbalanced state of the government on account of administration, monetary and budgetary aspect. Thus, known to this fact, inflation and FDI are always found related to one another (Mehmood \& Faridi, 2013). Investors always like to invest in a stable and balanced economy, instead. Therefore, inflation is to be in negative in relationship with FDI. In this respect, Sayek (1999) by the mean of impulse response of FDI to inflation, on account of rise in prices in Canada and their effects on inward USA investment, found that 7 percent of increase in inflation in Canada brought into being reduction of inward investment from USA by that of 1.9 percent and 0.3 percent of the rise in the investment back to domestic market of USA. Unstable rate of inflation is a measure of economic instability (Burnside \& Dollar, 1997). However, whether of being of its higher in the range or lower is to be yet focused-on for determining it as a reflector of economy instability (Ahn, Adji, \& Willett, 1998). In general, the tendencies of effects of inflation on FDI are always in negative (Li \& Liu, 2005; Naude \& Krugell, 2007), unlike of positive effects of the same explored in the study conducted on Pakistan by Awan, Zaman, and Khan, (2010).

\section{The Theoretical Background}

\subsection{The present section is to highlight some of the theories of FDI that are to pave the way of framing the study on the factors that dampen the consistent flow of FDI to a particular country.}

\subsubsection{Harrod Domar Model: The Growth Theory Foundations}

The idea behind mentioning Harrod (1939) and Domar (1946) Model which is indeed a theory of economic growth is a fact that for economic growth, FDI and accumulation of capital is necessarily required. The developments in this growth theory do not undermine the significance of capital accumulation that is a factor of economic growth such as infrastructure, business activities in a particular country, and support of government in enhancing the base of capital formation. Researchers have placed heavy emphasis in highlighting the need for investment for economic growth (Mehmood \& Hassan, 2015). However, this gap of investment, if pertains, is filled up by the mean of FDI.

\subsubsection{Eclectic Theory}

Dunning (2008) is of the view that the decisions of foreign investors towards carrying out the business activities across the headquarters are dependent upon the factors that pertain in country-specific and the variables (internal) that are to effect the base of trade and FDI. The theory mainly circulates around three dimensions, for example owner-specified (0); location-specific $(\mathrm{L})$ and lastly the internalization $(\mathrm{I})$. This theory is an interaction of macroeconomic theory of international trade on account of $(\mathrm{L})$ and microeconomic theory of firm $(\mathrm{O} \& \mathrm{I})$. The theory asserts that all of the three variables are indeed important in tracing out for the reasons of investment across the national borders.

For $\mathrm{O}$, the variables that act as influential are the tangible assets like the natural resources, capital as well as manpower. Nonetheless, intangibles also play a significant role which are the composite of information and technology, managerial, marketing and entrepreneurial skill and the governing systems that the organizations are following.

Factors concerning to $\mathrm{L}$, are referred to the market structure, the policies and legislations of the government of the host country, the political state and legal norms, and lastly the cultural environment. Here, further defining political state is to explore about the political parties and their incentive packages for the multinational enterprises. On account of legislations, there comes the element of rule of law and writ of the government.

Defining I component of the theory, it surrenders the explanations in terms of the build-in flexibility of a particular firm. It is the fact that multinational firms have a capacity and flexibility to market and produce in prevailing country by their own subsidiary, being operated in headquarter. In the meantime, it is seen that the local markets are not able to produce that could meet the requirement of the potential buyers and sellers therefore, multinational enterprises always attempt to choose the path of internalization for capturing certain degree of comparative advantage.

Repeating again, the variables those effect the transitioning of such production houses are related to political environment, geographical environment, taxation system, fiscal policy in terms of government expenditures and spending on investment activities, the regulatory framework of the government, the cultural environment, and the transportation and production costs (Dunning, 2008). 


\subsubsection{Investment Theory of a Firm}

The theories on investment presented by Barney (1991), Williamson and Masten (1995), Christie, Joye, and Watts (2003) are of the view point that opportunity cost of money and risk premium are the primary components of investment decision. Nevertheless, political instability, increasing cost of doing business, life threats, unsound macroeconomic base (like that of inflation, volatility in exchange rate), and bad governance always effect the future expected profit of firms (Feenstra \& Hanson, 2004).

\subsubsection{New Growth Theory and FDI}

Solow's (1956) growth theory titled "A Contribution to the Theory of Economic Growth" is considered as basic growth theory in economic literature. However, neo-classical growth theory of Solow suggests that economic growth and factors of production are the components that are related to the returns to scale of a firm. The idea behind this theory is the notion that FDI is a main contributor to economic growth and economic growth tends to be the factor that determines FDI in effectuality. Linking the factors like of saving rate, population growth rate and per capita income as the determinants of economic growth of which FDI is also one of the growth causing factors, by adding the technical change in the growth model, all such variables, in repel, tend to upset the flow of FDI in a particular country.

\section{Source of Data, Model Specification and Methodological Issues}

\subsection{Source of the Data}

The data (annual) is collected from various sources for the period of 1974 to 2014. The detail are given as in Table 1.

Table 1. (Variables, Source of Data \& Measurement)

\begin{tabular}{|l|l|}
\hline Variable & Data Source\& Measurement \\
\hline Foreign Direct Investment (FDI) & The World Bank; (Net Inflows, Current USD "Million") \\
\hline Gross Domestic Product (GDP) & Economic Survey of Pakistan; (Current USD "Million") \\
\hline Interest Rate (IR) & Economic Survey of Pakistan; (Annual \%) \\
\hline Trade Openness (TO) & Economic Survey of Pakistan; (Exports + Imports/ GDP X 100) \\
\hline Exchange Rate (ER) & State Bank of Pakistan; (Officially Announced against USD) \\
\hline Inflation (CPI) & Economic Survey of Pakistan; (Consumer Price Index, Annual \%) \\
\hline Labor Force (LB) & Economic Survey of Pakistan; (Economically active participants above 15 years of age as per ILO) \\
\hline Political Stability (PS) & $\begin{array}{l}\text { Dummy Variable; where 0 is assigned in year of no democratic government and 1 for the ruling period } \\
\text { of democratically elected government (Mehmood \& Faridi, 2013) }\end{array}$ \\
\hline Corruption (CR) & $\begin{array}{l}\text { Worldwide Governance Indicators, The World Bank; (Estimate of governance ranges from } \\
\text { approximately -2.5 (weak) to 2.5 (strong) governance performances). }\end{array}$ \\
\hline
\end{tabular}

\subsection{Model Specification}

After peeping into the problem statement, significance and scope of the study, this study proposes following model for the achievement of the objective that is furbished to be worked on. The model of the study appears in Equation [1].

[1] $F D I_{t}=\beta_{0}+\beta_{1} G D P+\beta_{2} I R+\beta_{3} T O+\beta_{4} E R+\beta_{5} C P I+\beta_{6} L B+\beta_{7} P S+\beta_{8} C R+\varepsilon_{t}$

Where

$F D I=$ Foreign Direct Investment

$G D P=$ Gross Domestic Product

$I R=$ Interest Rate

$T O=$ Trade Openness

$E R=$ Exchange Rate

$\mathrm{CPI}=$ Consumer Price Index (Inflation)

$L B=$ Labor Force participation

$P S=$ Political Stability

$C R=$ Corruption 


$$
\begin{aligned}
& \varepsilon_{t}=\text { error term } \\
& \beta_{1}, \beta_{2} \ldots . \beta_{8} \text { are the coefficients, } \beta_{0} \text { is an intercept of the model and } \varepsilon_{t} \text { is an error term. }
\end{aligned}
$$

\subsection{Methodologies and Analytical Techniques}

On account of aiming for the empirical investigation of the relationship between the opted socioeconomic variables in this study and to accomplish the desired objectives of the study, the methodology persuades in following steps:

\subsubsection{Unit Root Test}

Before to establish cointegration among the series that either it exists or not and if exists, what is the intensity of effect of one independent variable on the dependent variables, there is a need to check for the order of stationary on each variable. Using standard unit root test defined by Dickey and Fuller (1979) helps to know the order of the integration of series of the data.

In this case, commonly used technique is of Augmented Dickey and Fuller (Mehmood \& Faridi, 2013; Akmal, Ahmad, Ahmad, \& Butt, 2007). Augmented version of Dickey and Fuller test usually bases upon following Equation [2].

$$
\Delta y_{t}=\alpha_{1}+\alpha_{2} t+\delta y_{t-1}+\beta_{i} \sum_{t=1}^{m} \Delta y_{t-1}+\mu_{t}
$$

Where $\mu_{t}$ is error term (white noise), ${ }^{y_{t}}$ regressors in series, $\delta$ explains state of stationarity and

$$
\Delta y_{t-1}=\left(y_{t-1}-y_{t-2}\right), \Delta y_{t-2}=\left(y_{t-2}-y_{t-3}\right) \text {, etc. }
$$

If the computed statistics of coefficient turnout to be less than its corresponding critical value, $y$ is to be considered stationary.

\subsubsection{Test of Long run relationship (Cointegration)}

Attempting to visualize long run relationship existence between the variables of the study, if all the series, at unit root test, turn stationary at different order of integration, i.e. either I (0) or I (1), cointegration among the same is to be found by the usage of ARDL approach. This method of looking into the degree of association between the variables of the study is indeed more powerful in analysis as compare to that of other conventional method(s) that are usually work-out for the said cause (Pesaran \& Shin, 1995).

To start with, Following is the specified model for unrestricted ECM that helps in tracing long-run relationship among the variables, in initial stage. Equation [3] describes the required functional form.

$$
\begin{aligned}
& \Delta F D I=\alpha+\beta_{1} F D I_{t-1}+\beta_{2} G D P_{t-1}+\beta_{3} I R_{t-1}+\beta_{4} T O_{t-1}+\beta_{5} E R_{t-1}+ \\
& \beta_{6} C P I_{t-1}+\beta_{7} L B_{t-1}+\beta_{8} P S_{t-1}+\beta_{9} C R_{t-1}+\sum_{I=0}^{P_{1}} \delta_{1} \Delta F D I_{t-i}+\sum_{I=0}^{P_{2}} \delta_{2} \Delta G D P_{t-i}+ \\
& \sum_{I=0}^{P_{2}} \delta_{3} \Delta I R_{t-i}+\sum_{I=0}^{P_{4}} \delta_{4} \Delta T O_{t-i}+\sum_{I=0}^{P_{3}} \delta_{5} \Delta E R_{t-i}+\sum_{I=0}^{P_{6}} \delta_{6} \Delta C P I_{t-i}+\sum_{I=0}^{P_{7}} \delta_{7} \Delta L B_{t-i}+ \\
& +3] \quad+\sum_{I=0}^{P_{8}} \delta_{8} \Delta P S_{t-i}+\sum_{I=0}^{P_{9}} \delta_{9} \Delta C R_{t-i}+\varepsilon_{t}
\end{aligned}
$$

Where $\beta_{i}, \delta_{i}$ and $\Delta$ are the long-run multipliers, short-run dynamic parameters and a sign of first difference. However, ${ }{ }_{t}$ is white noise error term.

Once the relationship in long-run exists, the coefficient on all the variables are to be found by following Equation [4]

$$
\begin{aligned}
& \Delta F D I=\alpha+\sum_{I=0}^{P_{4}} \eta_{1} \Delta F D I_{t-i}+\sum_{l=0}^{P_{2}} \eta_{2} \Delta G D P_{t-i}+ \\
& \sum_{I=0}^{P_{3}} \eta_{3} \Delta I R_{t-i}+\sum_{I=0}^{P_{4}} \eta_{4} \Delta T O_{t-i}+\sum_{I=0}^{P_{5}} \eta_{5} \Delta E R_{t-i}+\sum_{l=0}^{P_{6}} \eta_{6} \Delta C P I_{t-i}+\sum_{l=0}^{P_{3}} \eta_{7} \Delta L B_{t-i}+ \\
& {[4] \quad+\sum_{I=0}^{P_{s}} \eta_{8} \Delta P S_{t-i}+\sum_{I=0}^{P_{5}} \eta_{9} \Delta C R_{t-i}+\varepsilon_{t} }
\end{aligned}
$$


Where $\alpha$ is coefficient, ${ }^{\eta}$ and $\mathcal{E}$ are long run parameters and error term.

ARDL involves two steps, when aim is to look into long-run relationship among variables that are specified in a particular equation (Pesaran, Shin, \& Smith, 2001); first is, as explained earlier, the long-run relationship estimation and second step applies only when long-run relationship is restored (Narayan, 2005). The asymptotic critical values, given by Pesaran and Pesaran (1997) and Pesaran et al. (2001) ${ }^{1}$. If upper bound value appears to be as low to the computed Fstatistics, the authentication is to get confirmed on long-run relationship existence and vice versa. However, if falls within two bound a value, inconclusive is supposed to be the results of the analysis.

\subsubsection{Test of Short run relationship}

After long run relationship among the selected variables of the present study is established, the next approach of methodology is to work out for the finding of the fact that either there appears short run relationship between the variables. It is found by the exercise of ECM. Equation [5] is the specified version of ECM.

Following Equation [5] is furbished to analyze the short-run dynamics.

$$
\begin{aligned}
& \Delta F D I=\alpha+\sum_{I=0}^{P_{1}} \lambda_{1} \Delta F D I_{t-i}+\sum_{I=0}^{P_{2}} \lambda_{2} \Delta G D P_{t-i}+ \\
& \sum_{I=0}^{P_{2}} \lambda_{3} \Delta I R_{t-i}+\sum_{I=0}^{P_{4}} \lambda_{4} \Delta T O_{t-i}+\sum_{I=0}^{P_{5}} \lambda_{5} \Delta E R_{t-i}+\sum_{I=0}^{P_{5}} \lambda_{6} \Delta C P I_{t-i}+\sum_{I=0}^{P_{7}} \lambda_{7} \Delta L B_{t-i}+ \\
& +\sum_{I=0}^{P_{s}} \lambda_{8} \Delta P S_{t-i}+\sum_{I=0}^{P_{5}} \lambda_{9} \Delta C R_{t-i}+\omega E C M+\varepsilon_{t}
\end{aligned}
$$$$
\text { [5] }
$$

Where $\lambda$ show short-run parameters. Disequilibrium in short-run that adjusts towards equilibrium while in the move towards of long-run is hereby viewed-in as $\omega E C M$. However, negativity on account of sign of ECM term and its statistical significance is mandatory to come up with.

\section{Empirical Results and Discussions}

\subsection{Test of Stationarity}

In time series analysis when the size of data is large, non stationarity of the series has to be checked. Table 2 represents the test of stationarity. The null hypothesis represents that the series is non-stationary, opposite to alternate hypothesis (Dickey \& Fuller, 1979). The Table makes it evident that all the variables turnout to be stationary. However, some at level and others at trend with different lags. Thus, ARDL is used.

Table 2. Augmented Dickey Fuller Unit Root Test

\begin{tabular}{|c|c|c|c|c|}
\hline Variables & t- Statistics & Lag & Probability & Conclusion \\
\hline FDI & $-2.15^{*}$ & 6 & 0.03 & $\mathrm{I}(0)$ \\
\hline GDP & $-4.12^{* *}$ & 8 & 0.00 & $\mathrm{I}(1)$ \\
\hline IR & $-3.04^{*}$ & 9 & 0.03 & $\mathrm{I}(0)$ \\
\hline TO & $-7.77^{* *}$ & 9 & 0.00 & $\mathrm{I}(1)$ \\
\hline ER & $-3.69^{* *}$ & 3 & 0.00 & $\mathrm{I}(1)$ \\
\hline CPI & $-3.29^{*}$ & 9 & 0.02 & $\mathrm{I}(0)$ \\
\hline LB & $-6.64^{* *}$ & 9 & 0.00 & $\mathrm{I}(1)$ \\
\hline PS & $-12.17^{* *}$ & 9 & 0.00 & $\mathrm{I}(1)$ \\
\hline CR & $-3.22^{*}$ & 9 & 0.02 & $\mathrm{I}(0)$ \\
\hline
\end{tabular}

\subsection{Bound Testing}

We have used ordinary least square on Equation [3] to find F-statistics by the application of Wald test. However, it is done so by the usage of Schwarz Bayesian Criterion (SBC) for the determination of lag length of variables. ${ }^{2}$ Table 3 represents the F-test of cointegration by applying the Walt test. The table clarifies that computed F-Statistics is above upper bound value, exported from Narayan (2005). Thus, we state that cointegration exists among the variables in long-run.

\footnotetext{
${ }^{1}$ Here it is assumed that all of the variables are integrated at I(0), while the other assumption is of the integration of the variables at I(1).

${ }^{2}$ The suggested optimum lag length in SBC is 2, for better results.
} 
Table 3. F-Test for Cointegration (Computed by Wald Test)

\begin{tabular}{|c|c|c|c|}
\hline Equation [4] & F-Statistics Calculated & Upper\& Lower Critical Value & Conclusion \\
\hline FDI/GDP, IR, TO, ER, CPI, LB, PS, CR & 6.72 & $5.68 \& 3.68$ & Existence of Cointegration \\
\hline
\end{tabular}

Critical values got from Narayan (2005).

\subsection{Long-run Coefficients}

As all the variables, on account of stationarity, are not settled at first difference intercept, and technique of bound testing has established that there exist long-run relationships between the variables, afterwards, Table 4 in the row is to interpret the coefficients on all the variables.

Table 4. (Long-run Coefficients: Dependent Variable FDI)

\begin{tabular}{|c|c|c|}
\hline Regressor(s) & Coefficient & $t$-Statistics \\
\hline GDP & 0.03 & 1.37 \\
\hline IR & -141.77 & -1.34 \\
\hline TO & -16518.20 & -1.16 \\
\hline ER & -303.13 & -2.57 \\
\hline CPI & 54.25 & 0.83 \\
\hline LB & 548.75 & 2.42 \\
\hline PS & -934.34 & -1.40 \\
\hline CR & -2506.50 & -2.27 \\
\hline \multicolumn{2}{|l}{} \\
\hline
\end{tabular}

FDI apparently looks as imposing burden on existing industries due to shifting their production towards capital intensive mode of assembling goods and services, to be in the race of competitive business inflows. Despite of this, FDI is seen by Ragazzi (1973) as a motive of controlling productive activity of economy that it flows towards. Realizing such facts, there is a realization that FDI contributes, in positive, towards the GDP of economy, (Bashir et al., 2014), mainly by expanding jobs along with unveiling facts of technology improvement (Ataullah et al., 2004).

Our results appear in line with the previous results, explored by Tsai (1994), Mohiudin and Salman (2011), and Mehmood and Faridi (2013); that GDP and FDI associated with one another, indeed in positive.

Interest rate is a cost of borrowing capital. In economies like Pakistan where, though less of export oriented, plenty of established firms exist in different race of business, new investors are found as feeling less satisfied if cost of borrowing capital as well as exchange rates are volatile in respect of upward movement. Therefore, our results are well justified in publishing that interest rate and exchange rate both, as found earlier by Zaman et al. (2012), effect FDI inflows in inverse, unlike Rehman et al. (2011) and Mehmood and Faridi (2013), on account of exchange rate, for exclusive.

Investment theory of firm described factors like of bad governance, uncertain law and order that uncertain the future profit expectation. Situation of business in Pakistan are shaded out as inappropriate and perhaps risky due to law and order problem as well as severe energy crisis. Knowing such facts, even trade openness don't have any positive effect on FDI, even government facilitates trade. Meaning that, macroeconomic situations, if uncertain, never attract such inflows (Barney, 1991).

Being not less convincing was an argument of Ataullah et al. (2004) that fixed into the frame of empirical findings that FDI contribute to GDP via sourcing domestic job creation. It shows that labor force and FDI have relationship and causality, as argued by Mehmood and Faridi (2013). Our results, unsurprisingly, appear in positive on labor force participation and FDI. Excessive labor force participation lowers wages via competitiveness and thus, in conclusion, affects FDI in positive.

Circulation of money is quite high in Pakistan. In economic terms, it is spoken as to bring inflation, if it is higher to productive capacity. However, it is completely adapted, i.e. peoples' earnings are well adjusted for price rise, never effect the demand. Thus, experiencing high demand due to low saving rate initiates investors to work on their businesses, uninterrupt. Therefore, even if a prices rise (inflation) effects business not like discouraging, rather on account of FDI leads to have direct association to one another.

Buckley and Casson (1976) spoke about not only macroeconomic rather social factors, as expressed in ideologies by Williamson and Masten (1995), and Christie et al. (2003), such as political instability and its effects on FDI inflows. This study examined for the same cause. However, found political stability as negatively effecting FDI inflows. Apart from this that; political stability adds to economic wellbeing (GDP growth), as found by Younis et al. (2008), mixed results are 
found while looking for effects of political stability towards FDI inflows 3 .

For Pakistan, Our results suggest that more stable is political base, falling is trend of FDI. It is because political parties in Pakistan are more public oriented than that of setting some aspects of favoring FDI. Since independence, as majority of the eras' in past are embodied with the Marshall Laws (Dictator-ship/ No Democracy), therefore, political parties are usually seen busy in providing least attention towards how to motivate FDI and more towards basic needs provisioning to the public. Along with this fact, results on political stability are insignificant in their impact on FDI inflows. Thus, looking into past studies for reference, need is to see the intensity of effect of political stability to FDI, too.

Looking into social factors that influence FDI, this study analyzed significant and negative effects of corruption on FDI inflows 4 . Political stability and corruption which are social aspects that effect FDI are found to be different in the level of significance. Corruption and its linkage with FDI is highly significant, in contrast to political stability. It appears that political stability though possess negative effect on FDI, near to less justified, thereby insignificant, opposite to corruption. It means that corruption is more meaningful and strong in determining FDI than to political stability.

\subsection{Error Correction Model}

Hereafter, in order to see the short run relationship between the variables of the study, the results of ECM are seeable in Table 5.

Table 5. (Short-Run relationship)

\begin{tabular}{|c|c|c|c|}
\hline & \multicolumn{3}{|c|}{ Dependent variable= FDI } \\
\hline Independent variable FDI & Coefficient & Standard Error & t-statistics \\
\hline Constant & -2186.60 & 2334.70 & -0.94 \\
\hline $\mathrm{dGDP}$ & .001 & .006 & 1.44 \\
\hline $\mathrm{dIR}$ & -49.54 & 35.69 & -1.39 \\
\hline $\mathrm{dTO}$ & 3658.50 & 3809.70 & 0.96 \\
\hline $\mathrm{dER}$ & -105.92 & 31.04 & -3.41 \\
\hline $\mathrm{dCPI}$ & 18.96 & 24.14 & 0.79 \\
\hline $\mathrm{dLB}$ & 191.75 & 85.09 & 2.25 \\
\hline $\mathrm{dPS}$ & -326.49 & 215.44 & -1.52 \\
\hline $\mathrm{dCR}$ & -875.83 & 359.99 & -2.43 \\
\hline $\mathrm{ECM}$ & -0.35 & 0.12 & -2.94 \\
\hline R-squared: 0.63 & \multicolumn{3}{|}{} \\
F-Statistics: 4.85 & \multicolumn{3}{|}{} \\
R Bar squared: 0.48 & \multicolumn{3}{|l}{} \\
\hline
\end{tabular}

The results of ECM explain that GDP, trade openness, inflation and labor force participation are positive in affecting FDI. Apart from this, interest rate and exchange rate affect FDI negatively. The major findings are on political stability and corruption that validate the findings of Mehmood and Faridi (2013), where both affect the FDI negatively.

The ECM coefficient is negative and indeed significant that proof that 35 percent of the disequilibrium is adjusted towards the tendency towards the long-run.

\section{Policy Suggestion and Conclusion}

This study is an effort that has been carried out basing upon the empirical analyzes for looking into the determinants of FDI in Pakistan. It is perhaps not a pioneer study at its own. However, the results have contributed in developing some interesting thoughts i.e. trade openness that has resulted in negatively effecting FDI. Apart from this, political stability has insignificant and negative effect on FDI in Pakistan. Therefore, shows that democratically elected government is to do nothing with FDI, though insignificant the findings are. Nevertheless, corruption, as found earlier, possess a factuality of inverse relationship to FDI.

Proper policy mix is required, as argued by Burnside and Dollar (1997, 2000, and 2004) that affect the economy. Same facts are explored in this research that are to be treated with due care by the government of Pakistan, basing upon the findings of this study, while defining measures those are to be executed for favorable flow of FDI. For example,

\footnotetext{
3 See, Kobrin (1984), Scheider and Frey (1985), Knack and Keefer (1995), Mehmood and Faridi (2013).

${ }^{4} F o r$ comparison and acknowledgement, see Aburine (2010), Shahbaz and Rahman (2010), Zhou (2007), Al-Sadig (2009), Habib and Zurawicki (2002), Akcay (2001) and Laran and Tavare (2004).
} 
reduced level of interest rate and higher exchange rate upset FDI, therefore, need is to keep them adjusted accordingly. Seemingly population rise that contribute to labor force participation and hereafter FDI, in positive, is to be embodied with sufficient investment in preparing the labor for better performance that is hereafter to be taken as valuable asset for foreign investors. While being worry-less on account of inflation, there is a need to have policies to settle down issues of corruption which are rusting out vital inflows i.e. FDI to Pakistan.

\section{References}

Abbas, Q., Akbar, S., Nasir, A. S., Ullah, H. A., \& Naseem, M. A. (2011). Impact of foreign direct investment on gross domestic product (A case study of SAARC countries). Global Journal of Management and Business Research, 11(8), 34-40.

Aburine, T. U. (2010). Impact of corruption on bank profitability in Nigeria. Euro Economica, 23(2), 50-57.

Ahn, Y. S., Adji, S. S., \& Willet, T. D. (1998). The effects of inflation and exchange rate policies on direct investment to developing countries. International Economic Journal, 12(1), 95-104.

Akcay, S. (2001). Is corruption an obstacle for foreign investors in developing countries? Cross country evidence. YapiKredi Economic Review, 12(2), 27-34.

Akhtar, M. H. (2000). The determinants of foreign direct investment in Pakistan: An econometric analysis. The Lahore Journal of Economics, 5(1), 1-22.

Akmal, M. S., Ahmad, Q. M., Ahmad, M. H., \& Butt, M. S. (2007). An empirical investigation of the relationship between trade liberalization and poverty reduction: A case for Pakistan. The Lahore Journal of Economics,12(1), 99-118.

Al-Sadig, A. (2009). The effects of corruption on FDI inflows. Cato Journal, 29(2), 267-297.

Aqeel. A., Nishat, M., \& Bilquees, F. (2005).The Determinants of Foreign Direct Investment in Pakistan. Pakistan Institute of Development Economics, The Pakistan Development Review, 43(4), 651-664.

Ataullah, A., Cockerill, T., \& Le, H. (2004). Financial liberalization and bank efficiency: a comparative analysis of India and Pakistan. Applied Economics, 36(17), 1915-1924.

Awan, M. Z., Zaman, K. U., \& Khan, B. (2010). Determinants of foreign direct investment in service sector of Pakistan: an econometric approach. IBA Business Review, 5(2), 167-180.

Barney, J. (1991). Firm resources and sustained competitive advantage. Journal of Management, 17(1), 99-120.

Barrell, R., \& Pain, N. (1996). An econometric analysis of US foreign direct investment. The Review of Economics and Statistics, 78(2), 200-207.

Bashir, T., Mansha, A., Zulfiqar, R., \& Riaz, R. (2014). Impact of FDI on economy growth: A comparison of South Asian States \& China. European Scientific Journal, 10(1), $446-469$.

Borensztein, E., De Gregorio, J., \& Lee, J. W. (1998). How does foreign direct investment affect economic growth? Journal of International Economics, 45(1), 115-135.

Buckley, P. J., \& Casson, M. (1976). The future of the multinational enterprises (25th anniversary ed.). London: MacMillan.

Burnside, C., \& Dollar, D. (1997). Aid, policies and growth (Policy research working paper No. 1777). Washington, DC: The World Bank Development Research Group.

Burnside, C., \& Dollar, D. (2000). Aid policies and growth. The American Economic Review, 90(4), 847-868.

Burnside, C., \& Dollar, D. (2004). Aid, policies, and growth: Revisiting the evidence. (Policy research working paper No. 3251). Washington, DC: The World Bank Policy Research.

Caves, R. E. (1974). Multinational firms, competitions, and productivity in host-country markets. Econometrica, 41(162), 176-193.

Chaudhary, A. R., Iqbal, A., \& Gillani, S. Y. M. (2009).The nexus between higher education and economic growth: An empirical investigation for Pakistan. Pakistan Journal of Commerce and Social Science, 3(1), 1-9.

Christie, A. A., Joye, M. P., \& Watt, R. L. (2003). Decentralization of the firm: Theory and evidence. Journal of Corporate Finance, 9(1), 3-36.

Dickey, D.A., \& Fuller, W.A. (1979). Distribution of the estimators for Autoregressive time series with a unit root. Journal of the American Statistical Association, 74(366), 427-431.

Domar, E. (1946). Capital expansion, rate of growth, and employment. Econometrica, 14(2), 137-147.

Dunning, J. H. (2008). Multinational enterprises and the global economy (2nd Edition). Northampton: Edward Elgar Publishing.

Feenstra, R. C., \& Hanson, G. H. (2004). Ownership and control in outsourcing to China: Estimating the property-right theory of the firm. Quarterly Journal of Economics, 120(2), 729-761.

Fry, M. J., Claessens, C. A., \& Burridge. (1995). Foreign direct investment, other capital flows and current account deficits: What causes what? (Working paper No. 1527). The World Bank.

Grosse, R., \& Trevino, L. J. (1996). Foreign direct investment in the United States: An analysis by country of origin. Journal of International Business, 27(1), 139-155.

Habib, M., \& Zurawicki, L. (2002). Corruption and foreign direct investment. Journal of International Business Studies, 33(2), 291-307.

Harrod, R. F. (1939). An essay in dynamic theory. The Economic Journal, 49(193), 14-33.

Javed, K., Falak, S., Awan, R., \& Ashfaq, M. (2012). Foreign direct investment, trade and economic growth: A comparison of selected South Asian Countries. International Journal of Humanities and Social Science, 2(5), 210-220.

Johansen, S., \& Juselius, K. (1990). Maximum likelihood estimation and inference on co-integration with application for the demand for money. Oxford Bulletin of Economics and Statistics, 52(2), 169-210.

Kesteloot, K., \& Veugelers, R. (1995). Stable R \& D cooperation with spillovers. Journal of Economics and Management Strategy, 4(4), 651-672. 
Khan, M. A., \& Khan, S. A. (2011). Foreign direct investment and economic growth in Pakistan: A sectoral analysis (Working paper No. 67). Islamabad: Pakistan Institute of Development Economics.

Kindleberger, C. P. (1969). American business abroad. The International Executive, 11(2), 11-12.

Knack, S., \& Keefer, P. (1995). Institutions and economic performance: cross country tests using alternative institutional measures. Economics \& Politics, 7(3), 207-227.

Kobrin, S. J. (1984). Expropriation as an attempt to control foreign firms in LDCs: Trends from 1960 to 1979. International Studies Quarterly, 28(3), 329-348.

Laran, B. F., \& Tavare, J. (2004). Does foreign direct investment decrease corruption? Caudernos de Economic, 41(123), $199-215$.

$\mathrm{Li}, \mathrm{X}$., \& Liu, X. (2005). Foreign direct investment and economic growth: an increasing endogenous relationship: World Development, 33(3), 393-407.

Mahmood, I., Ehsanullah, M., \& Ahmed, H. (2011). Exchange rate volatility \& macroeconomic variables in Pakistan. Business Management Dynamics, 1(2), 11-22.

Mehmood, K. A., \& Faridi, M. Z. (2013). Factors of garnishing across the border investments. Pakistan Journal of Commerce and Social Sciences, 7(3), 588-602.

Mehmood, K.A., \& Hassan, S. (2015). A study on mapping out alliance between economic growth and foreign direct investment in Pakistan. Asian Social Science, 11(15), 113-123.

Mohiudin, S. A., \& Salam, M. A. (2011). Determinants of foreign direct investment in Pakistan. Journal of Independent Studies and Research, 9(1), 117-124.

Narayan, K. P. (2005). The saving and investment nexus for China: Evidence from cointegration tests. Applied Economics, 37, $1979-90$.

Naude, W., \& Krugell, W. (2007). Investigating geography and institutions as determinants of foreign direct investment in Africa using panel data. Applied Economics, 39(10), 1223-1233.

Pesaran, M. H., \& Shin, Y. (1995). An autoregressive distributed lag modeling approach to cointegration analysis (DAE Working paper no. 9514). Department of Economics, University of Cambridge.

Pesaran, M. H., \& Pesaran, B. (1997). Working with Microfit 4.0: Interactive Econometric Analysis. Oxford: Oxford University Press.

Pesaran, M. H., Shin, Y., \& Smith, R. J. (2001). Bound testing approaches to the analysis of level relationship. Journal of Applied Econometrics, 16, 289-326.

Ragazzi, G. (1973). Theories of the determinants of direct foreign investment. Int. Monetary Fund Staff Papers, 20(2), 471-499.

Rehman, C. A., llyas, M., Mobeen, A. H., \& Akram, M. (2011).The impact of infrastructure on foreign direct investment: a case of Pakistan. International Journal of Business and Management, 6(5), p 268.

Safdari, M., \& Mehrizi, M. A. (2011). External debt and economic growth in Iran. Journal of Economics and International Finance, 3(5), 322-327.

Sarno, L., \& Taylor, M. P. (1999). Hot money, accounting labels and the permanence of capital flows to developing countries: An empirical investigation. Journal of Development Economics, 59(2), 337-364.

Sayek, S. (1999). FDI and inflation: theory and evidence (Unpublished Manuscript). Advisor to Duke University: Kimbrough, Kent.

Scheider, F., \& Frey, B. S. (1985). Economic and political determinants of foreign direct investment. World Development, 13(2), $161-175$.

Shahbaz, M., \& Rahman, M. M. (2010). Foreign capital inflows-growth nexus and role of domestic financial sector: An ARDL approach for Pakistan. Journal of Economic Research, 15(3), 207-231.

Shaikh, N. A., \& Ansari, I. A. (2011). Determinants of foreign direct investment and its statistical analysis. Journal of Independent Studies and Research, 9(2), 63-78.

Singh, H., \& Jun, K. (1995). Some new evidence on determinants of foreign direct investment in developing countries (Working paper No. 1531). The World Bank.

Solow, R. M. (1956). A contribution to the theory of economic growth. The Quarterly Journal of Economics, 7(1), 65-94.

Tsai, P. (1994). Determinants of foreign direct investment and its impact on economic growth. Journal of Economic Development, 19(1), 137-163.

Wheeler, D., \& Mody, A. (1992). International investment location decisions: the case of US firms. Journal of International Economics, 33(1-2), 55-76.

Williamson, O. E., \& Masten, S. E. (1995). Transaction Cost Economics, (Vol. 1) Northampton: Edward Elgar Pub.

Younis, M., Lin, X., \& Sharahili, Y. (2008). Political stability and economic growth in Asia. American Journal of Applied Sciences, 5(3), 203-208.

Yousaf, M. M., Hussain, Z., \& Ahmad, N. (2008).Economic evaluation of foreign direct investment in Pakistan. Pakistan Economic and Social Review, 46(1), 37-56.

Zaman, K., Rasheed, K., Khan, M. M., \& Ahmad, M. (2011). Panel data analysis of growth, inequality and poverty: evidence from SAARC countries. Journal of Yasar University, 21(6), 3523-3537.

Zaman, K., Shah, I. A., Khan, M. M., \& Ahmad, M. (2012). Macroeconomic factors determining FDI impact on Pakistan's growth. South Asian Journal of Global Business Research, 1(1), 79-96.

Zhang, K. H. (2001). How does foreign direct investment affect economic growth in China? Economics of Transition, 9(3), 679-693.

Zhou, Y. (2007). An empirical study of the relationship between corruption and FDI: with sample selection error correction (Unpublished Manuscript). University of Birmingham. 